Article

\title{
Adoption of Promising Fenugreek (Trigonella foenum-graceum L.) Genotypes for Yield and Quality Characteristics in the Semiarid Climate of Turkey
}

\author{
Yunus Güzel and Gülen Özyazıcı * (1)
}

check for

updates

Citation: Güzel, Y.; Özyazıcı, G. Adoption of Promising Fenugreek (Trigonella foenum-graceum L.) Genotypes for Yield and Quality Characteristics in the Semiarid Climate of Turkey. Atmosphere 2021, 12, 1199. https://doi.org/ 10.3390/atmos12091199

Academic Editor: Gianni Bellocchi

Received: 1 June 2021

Accepted: 7 September 2021

Published: 16 September 2021

Publisher's Note: MDPI stays neutral with regard to jurisdictional claims in published maps and institutional affiliations.

Copyright: (c) 2021 by the authors. Licensee MDPI, Basel, Switzerland. This article is an open access article distributed under the terms and conditions of the Creative Commons Attribution (CC BY) license (https:/ / creativecommons.org/licenses/by/ $4.0 /)$.
Department of Field Crops, Faculty of Agriculture, Siirt University, Siirt 56100, Turkey; yunusguzel@dsi.gov.tr

* Correspondence: gulenozyazici@siirt.edu.tr

\begin{abstract}
This study was conducted for two seasons from 2018 to 2020 to determine fenugreek genotypes yield and quality characteristics under semiarid climatic conditions. Fenugreek genotypes viz., Adana, Afghanistan, Gaziantep, Iraq, Kahramanmaraş, Kayseri, Mardin, Şanlıurfa with varieties of Berkem and Gürarslan were used as plant material in the research. Field trials were conducted with four replications according to the randomized complete block design. The results revealed that the time to emergence varied from 16.0 to 19.9 days, 50\% flowering from 160.9 to 170.4 days, and the vegetation period from 202.0 to 209.3 days. According to the results of two years of research, plant height varied from 64.60 to $78.70 \mathrm{~cm}$, first pod height from 25.26 to $41.76 \mathrm{~cm}$, pod width from 2.91 to $3.29 \mathrm{~mm}$, pod length from 10.07 to $12.60 \mathrm{~cm}$, number of pods per plant from 12.00 to 18.73 , number of seeds per pod from 12.55 to 15.55 , biological yield from 5.12 to $7.62 \mathrm{t} / \mathrm{ha}^{-1}$, seed yield from 0.91 to $1.38 \mathrm{t} / \mathrm{ha}^{-1}$, harvest index from 17.91 to $24.35 \%$, thousand-seed weight from 13.87 to $17.45 \mathrm{~g}$, fatty oil content from 5.18 to $9.16 \%$, fatty oil yield from 49.3 to $111.6 \mathrm{~kg} \mathrm{ha}^{-1}$, and the trigonelline ratio varied from 0.71 to $1.32 \%$. Statistically significant differences $(p \leq 0.05)$ were observed for the pod width, while highly significant differences $(p \leq 0.01)$ were observed for all other parameters. According to the research results, Mardin, Kayseri, and Adana genotypes were statistically in the same group with Berkem cultivar in terms of seed yield. A higher fatty oil content was obtained in the Afghanistan genotype (9.16\%) than in the Berkem cultivar (8.11\%). Gaziantep, Mardin, Şanliurfa, and Kayseri genotypes contained higher trigonellin than the Berkem and Gürarslan varieties. The obtained information was the result of the Mardin, Kayseri, Adana, Gaziantep, and Afghanistan genotypes that can be used in breeding studies.
\end{abstract}

Keywords: fenugreek; Trigonella foenum-greacum; genotypes; semiarid; yield

\section{Introduction}

Of the 422 thousand flowering plant taxa globally, approximately 72 thousand are utilized and five thousand are subject to trade globally [1]. Turkey is host to nine thousand plant species, of which approximately 500 are used for drugs or fragrance production, as a country located at the intersection of Mediterranean, European, and Iran-Turan gene centers.

Cultivation of medicinal and aromatic plants dates back to prehistoric times [2] as an antiseptic and for other therapeutic properties [3,4], as well as taste and aroma sources for foods [5]. An important ancient medicinal and aromatic plant in the traditional medicine and spice industry is fenugreek in Turkey. Fenugreek seeds are consumed as a spice, and all plant parts are used as animal feed [6,7]. Its seeds are rich in vitamins, minerals, and proteins [8,9], and all other plant parts are also rich in antioxidants, saponins, alkaloids, phenolic acids, flavonoids, phytochemicals, and other medicinal metabolites [10,11], which employ the whole plant in traditional medicine $[12,13]$.

Fenugreek is taxonomically in the Fabales order, Fabaceae (legumes) family, and Trigonella genus. Specie Trigonella foenum-graecum L. is cultured in Turkey [9]. A total 
of 713 tons of fenugreek seeds were produced from 652 hectares of land during 2020 in Turkey [14]. A significant increase in fenugreek acreage has been observed during the last five years. With sharp aromatic characteristics [15], fenugreek is extensively used for the production of pastrami (dried meats, tinned) and breakfast sauces in Turkey [8]. India is one of the world's leading countries that produces and exports fenugreek [16]. China, Morocco, and Turkey are also top fenugreek exporting countries [9].

In the cold climatic conditions of Turkey, fenugreek is produced in the summer periods, but in warm or hot locations, the cultivation period is winter, or sowings start in early spring [17]. Studies that included different Trigonella foenum-graecum varieties were conducted in Turkey's temperate [18-20] and cold climatic conditions [21,22]. Fenugreek is well adapted to different climatic and edaphic conditions [23], but agronomic characteristics such as growth requirements, seed yield, and quality vary between genotypes [24]. Previous literature suggested that genetic and environmental factors greatly influence the medicinal and aromatic plants' chemical and biological properties $[25,26]$. Studies on yield and quality characteristics are required to determine superior fenugreek genotypes adapted to different ecological conditions. Therefore, this research was conducted to determine some fenugreek genotypes' yield performance and quality characteristics in Turkey's semiarid Anatolian climatic conditions.

\section{Materials and Methods}

\subsection{Location and Duration}

The study was performed in the Siirt province of Turkey in semiarid Southeastern Anatolia conditions within the 2018-2020 growth seasons (Figure 1).

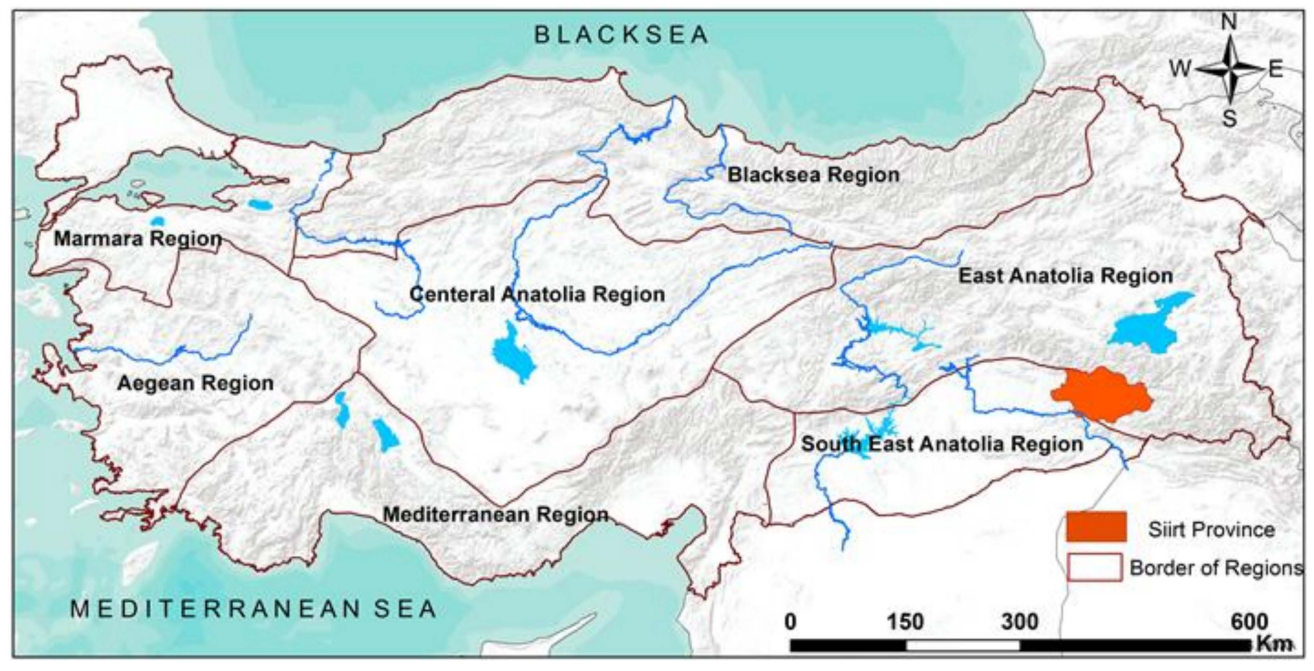

Figure 1. Research area location map (Siirt province is red-colored on map).

\subsection{Climatic Conditions}

When climatic data for the growth period (November-June) were analyzed, it was observed that the average temperature in the first year (2018-2019 season) was slightly lower than in the second year (2019-2020 season), whereas the total amount of precipitation was higher in the first year. Total precipitation for both years of the study was higher than the long-term average (Table 1). 
Table 1. Climatic data of the research site for long term (1981-2019) and research years [27].

\begin{tabular}{|c|c|c|c|c|c|c|c|c|c|}
\hline \multirow[b]{2}{*}{ Months } & \multicolumn{3}{|c|}{$\begin{array}{l}\text { Average Temperature } \\
\left({ }^{\circ} \mathrm{C}\right)\end{array}$} & \multicolumn{3}{|c|}{$\begin{array}{c}\text { Relative Humidity } \\
(\%)\end{array}$} & \multicolumn{3}{|c|}{$\begin{array}{c}\text { Total Precipitation } \\
\text { (mm) }\end{array}$} \\
\hline & $\begin{array}{l}\text { Long } \\
\text { Term }\end{array}$ & $\begin{array}{l}2018- \\
2019\end{array}$ & $\begin{array}{c}2019- \\
2020\end{array}$ & $\begin{array}{l}\text { Long } \\
\text { Term }\end{array}$ & $\begin{array}{l}2018- \\
2019\end{array}$ & $\begin{array}{l}2019- \\
2020\end{array}$ & $\begin{array}{l}\text { Long } \\
\text { Term }\end{array}$ & $\begin{array}{l}2018- \\
2019\end{array}$ & $\begin{array}{l}2019- \\
2020\end{array}$ \\
\hline November & 10.6 & 11.0 & 11.9 & 62.7 & 76.2 & 50.2 & 74.3 & 93.6 & 51.4 \\
\hline December & 5.1 & 6.6 & 7.5 & 72.5 & 82.4 & 75.0 & 90.6 & 188.6 & 75.8 \\
\hline January & 3.2 & 4.0 & 3.5 & 72.5 & 72.2 & 72.7 & 81.0 & 94.0 & 70.6 \\
\hline February & 4.7 & 5.7 & 3.7 & 67.5 & 66.9 & 73.0 & 98.4 & 98.6 & 158.6 \\
\hline March & 9.2 & 8.3 & 11.1 & 61.3 & 67.4 & 63.1 & 112.5 & 185.2 & 222.4 \\
\hline April & 14.2 & 11.9 & 14.1 & 58.4 & 66.5 & 60.2 & 103.5 & 167.0 & 158.8 \\
\hline May & 19.8 & 21.9 & 20.8 & 50.1 & 41.8 & 47.1 & 63.1 & 63.0 & 40.4 \\
\hline June & 25.9 & 29.1 & 27.2 & 33.9 & 34.7 & 26.6 & 9.1 & 9.4 & 0.2 \\
\hline Total/Average & 11.6 & 12.3 & 12.5 & 59.9 & 63.5 & 58.5 & 632.5 & 899.4 & 778.2 \\
\hline
\end{tabular}

The total amount of precipitation in the first three months (November, December, and January) of the second year of the study was nearly half of the first year (376 $\mathrm{mm}$ in the first year compared to $198 \mathrm{~mm}$ in the second year). In total, between November and June, there was $121 \mathrm{~mm}$ less rainfall in the second year compared to the first year of research. According to the soil climate regime of the Newhall simulation model [28], it was observed that the study site had a thermic soil temperature regime and a xeric (dry xeric in the subgroup) soil moisture regime (Figure 2).

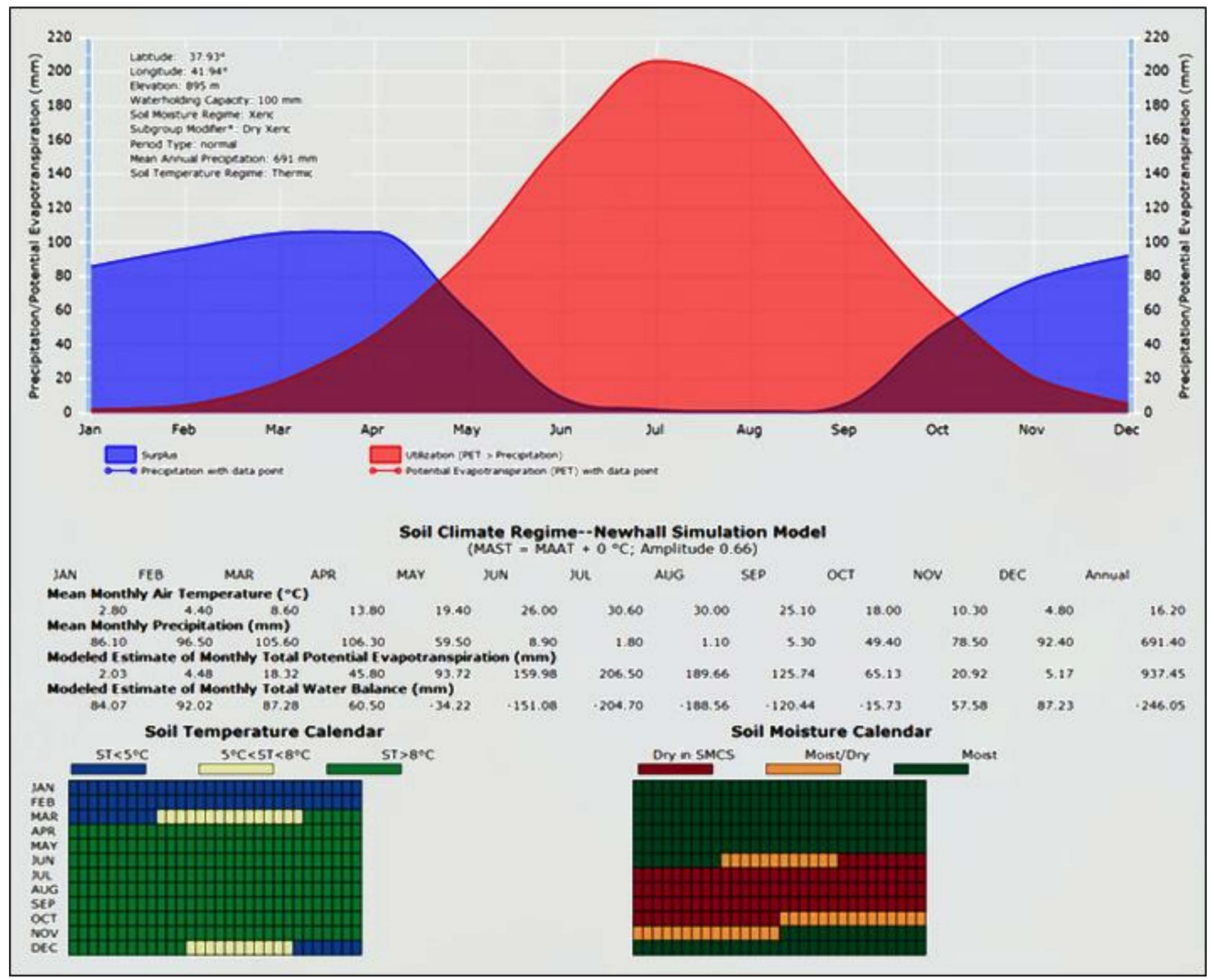

Figure 2. Soil moisture and temperature regime diagrams according to the Newhall simulation model.

\subsection{Soil Properties}

Soil samples from the experimental field were collected from 0 to $20 \mathrm{~cm}$ depth and analyzed before trials. The research soils were clay and clay-loam textured, slightly alkaline, salt-free, and poor in organic matter, containing medium (2018-2019) and low (2019-2020) amounts of lime, medium (2018-2019) and high (2019-2020) amounts of available phos- 
phorus, and sufficient available potassium (Table 2). The experiment fields in the second year were sandy, low in clay, lime-free, and rich in available phosphorus and potassium. Some physical and chemical properties of the soil samples are given in Table 2.

Table 2. Some physical and chemical soil properties of the trial fields.

\begin{tabular}{ccc}
\hline Soil Properties & Values (2018-2019) * & Values (2019-2020) * $^{*}$ \\
\hline Clay (\%) & 58.00 & 38.90 \\
Sand (\%) & 28.00 & 43.10 \\
Silt (\%) & 14.00 & 18.00 \\
pH & 7.95 & 7.70 \\
Organic matter (\%) & 1.58 & 1.64 \\
Lime $\left(\mathrm{CaCO}_{3}\right)(\%)$ & 10.5 & 2.79 \\
Electrical conductivity $\left(\mathrm{dS} \mathrm{m}^{-1}\right)$ & 0.575 & 0.180 \\
Available phosphorus $(\mathrm{P})\left(\mathrm{kg} \mathrm{P}_{2} \mathrm{O}_{5} \mathrm{ha}^{-1}\right)$ & 35 & 112 \\
Available potassium $(\mathrm{K})\left(\mathrm{kg} \mathrm{K}_{2} \mathrm{O} \mathrm{ha}^{-1}\right)$ & 1180 & 1882 \\
\hline
\end{tabular}

* Analyses were conducted in the Siirt University Science and Technology Application and Research Center Laboratory.

\subsection{Plant Materials}

The Berkem variety of fenugreek was registered by the Faculty of Agriculture, Dicle University. The Gürarslan variety was registered by the Faculty of Agriculture, Ankara University. However, the rest of eight genotypes named Adana, Afghanistan, Gaziantep, Irak, Kayseri, Kahramanmaraş, Mardin, and Şanlıurfa sourced from the Faculty of Agriculture, Kahramanmaraş Sütçü İmam University were used as plant materials. The Berkem variety has a medium height, flat pod-shaped, yellowish rectangular seeded plant with a scarce plumy erect/habitus and white flowers [29]. The Gürarslan variety has a $50-60 \mathrm{~cm}$ plant height, a seed yield of 1.4-1.6 t/ha, a thousand-seed weight of 16-21 g, a dark yellow coated seed, and a pod length of $8-10 \mathrm{~cm}$, and is a pale yellow-flowered and dark green leaf colored plant. Under optimal conditions, it produces $15-20$ pods per plant and 8-12 seeds per pod [30].

\subsection{Experimentation}

The previous crop to fenugreek in the rotation of the experimental field was wheat. After harvesting the previous crop, trial fields were deeply machine plowed, then prepared with a disc harrow and harrow. Field trials were performed with four replications based on a randomized complete block design. Inter row spacing for four rows in each plot was $30 \mathrm{~cm}$. The plot area was $1.2 \mathrm{~m} \times 4 \mathrm{~m}=4.8 \mathrm{~m}^{2}$. The distance between plots-plots and blocks-blocks was $1 \mathrm{~m}$.

Considering soil analysis (Table 2), $90 \mathrm{~kg} \mathrm{ha}^{-1}$ pure $\mathrm{P}_{2} \mathrm{O}_{5}$ as triple superphosphate fertilizer $\left(43-44 \% \mathrm{P}_{2} \mathrm{O}_{5}\right)$ was applied evenly in each plot during the first season of research. No phosphorus fertilizer was incorporated during the second season due to the sufficiency of available $\mathrm{P}$ in the soil. For both years, nitrogen $(\mathrm{N})$ fertilizer of urea $(46 \% \mathrm{~N})$ was applied to the opened rows at planting with an account of $30 \mathrm{~kg} \mathrm{ha}^{-1}$ as the starter fertilizer.

Weed free fields were sown on 06 November 2018 in the first year and on 15 November 2019 in the second year, at a seeding rate of $30 \mathrm{~kg} \mathrm{ha}^{-1}$. Mechanical weed control starts from the emergence of seedlings when required until the vegetation period. The experiments were carried out under rainfed conditions without any irrigation. Harvests were accomplished when the pods turned a yellowish-brown color. Around $0.5 \mathrm{~m}$ from both ends of the plant rows and both side border rows were cut out before harvesting the middle two rows in each plot. The plot area at/harvest was $1.8 \mathrm{~m}^{2}$. The seed yields obtained from the plots were analyzed by converting them to hectares.

\subsection{Data Collection}

To determine days to emergence, the number of days was counted from the sowing date until $50 \%$ of the plants were visible in the plot. The number of days was counted 
from sowing date to $50 \%$ of plants were flowered, for determination of days to flowering. The number of days was counted from the sowing date until $90 \%$ of the seeds (pods) on the plants turned yellowish-brown in the plot to determine the vegetation period. For biological yield determination, all harvested plants in each plot were weighed after harvest. Biological yield was divided into seed yield to calculate the harvest index.

For the assessment of trigonelline in fenugreek seeds, the ground samples were diluted 1:10 with methanol and mixed in a vortex. The mixture was prepared by a rotary shaker at $150 \mathrm{rpm}$ for $12 \mathrm{~h}$ before being filtered on Whatman filter paper and prepared for analysis. A high-performance liquid chromatography (HPLC) instrument (Agilent TC-C18) was used for trigonelline analysis. The flow rate was set at $1.0 \mathrm{~mL} / \mathrm{min}$ by the reverse-phase Inertsil ODS-3 $(4.6 \times 250 \mathrm{~mm})$ column. The mobile phase $(95: 5, v / v)$ was adjusted to $\mathrm{pH} 3.5$ with methanol purified water and hydrochloric acid. Measurements were made at $267 \mathrm{~nm}$ at a room temperature of $27^{\circ} \mathrm{C}$. Trigonelline analysis was conducted in the first year of the study by combining plots of the same genotypes. Therefore, trigonelline ratio values were not subjected to variance analysis.

\subsection{Statistical Analysis}

The data obtained from the research were subjected to the homogeneity test. The data were found to be homogeneous. Combined variance analysis was performed according to the Randomized Complete Blocks design on two-year data. Based on the F test results, the differences between the groups were determined by the Tukey multiple comparison test [31].

\section{Results and Discussion}

\subsection{Crop Phenology}

The time to emergence, time to $50 \%$ flowering, and vegetation period of fenugreek genotypes varied between 16.0 and 19.9 days, 160.9 and 170.4 days, and 202.0 and 209.3 days, respectively (Figures 3-5). However, the lowest values of time to emergence, time to 50\% flowering and vegetation period were observed in the Gaziantep genotype. The highest of all these parameters were observed in the Iraq and Afghanistan genotypes. [32] It was concluded that the flowering date and flowering date ending time were the important traits of fenugreek, which significantly influenced the yield.

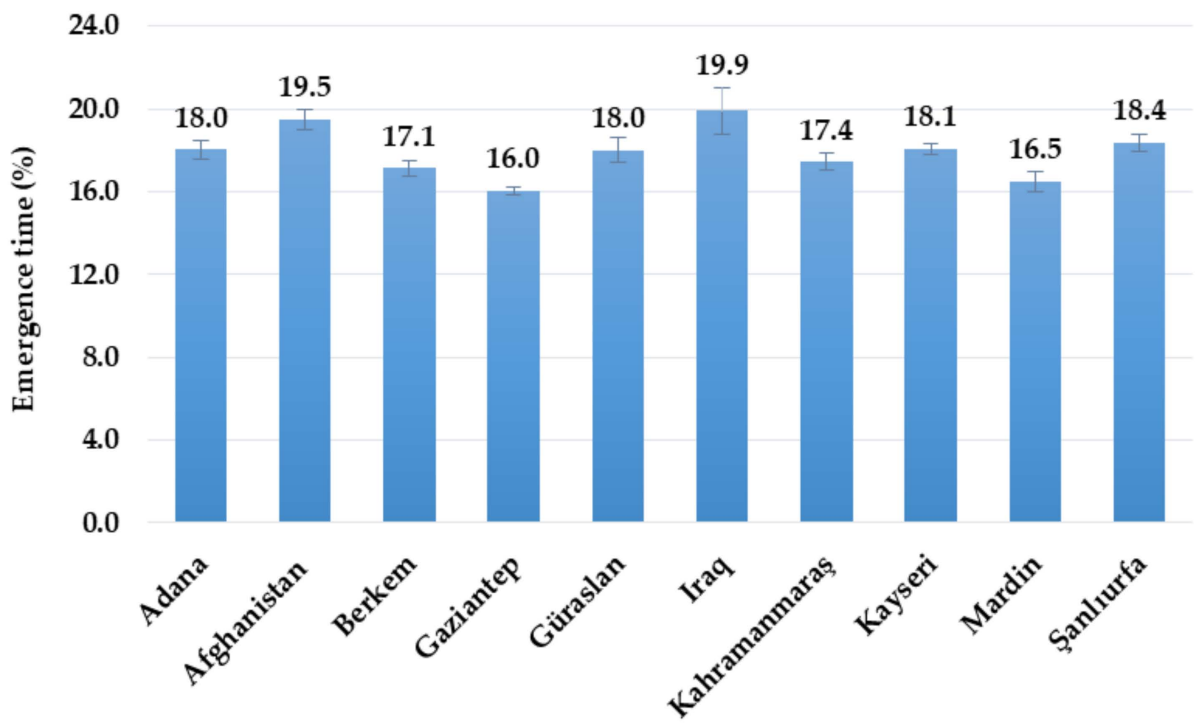

Figure 3. Average values for time to emergences for fenugreek genotypes. 
176.0

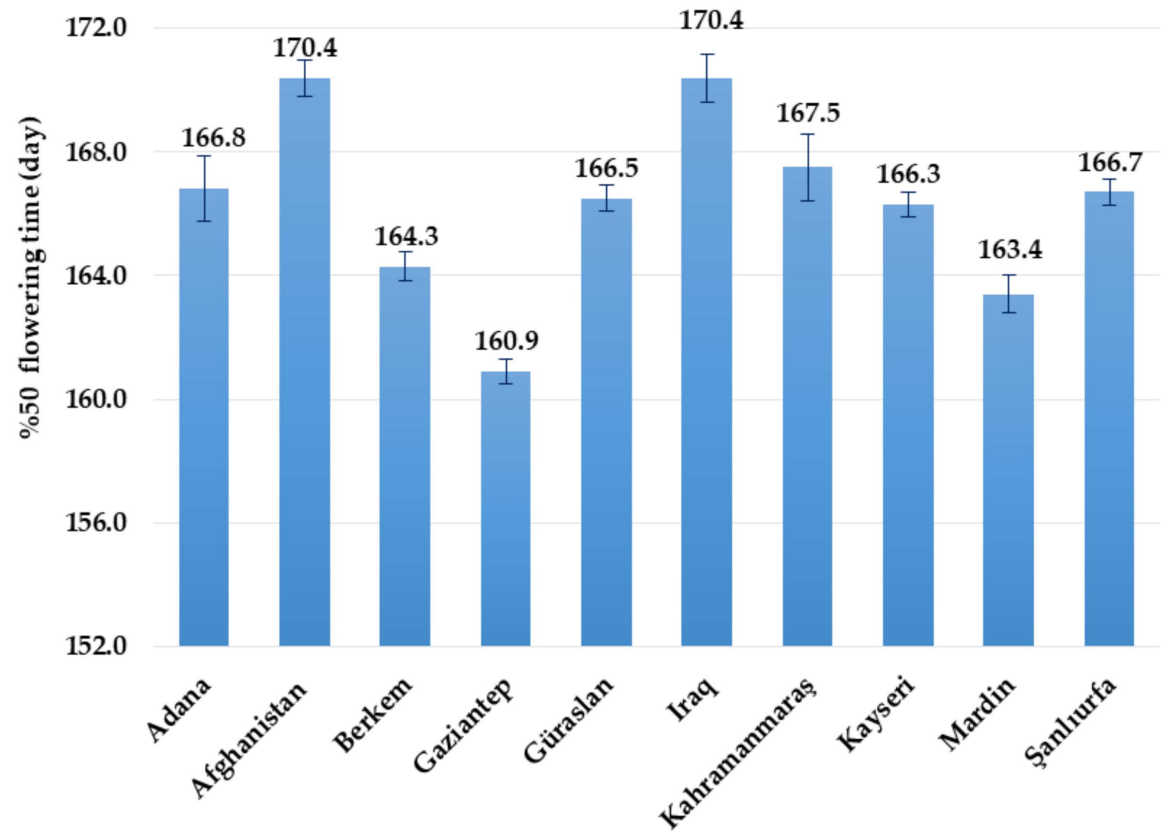

Figure 4. Average 50\% flowering times for fenugreek genotypes.

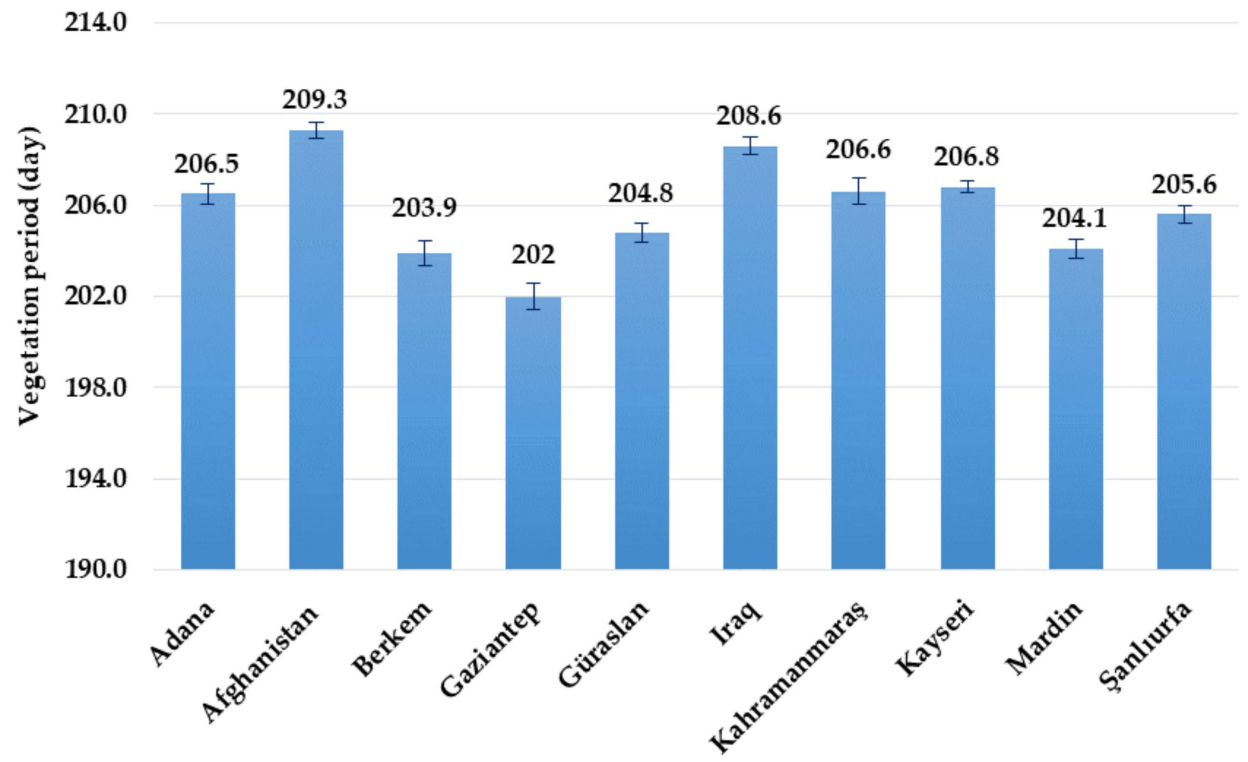

Figure 5. Average vegetation periods for fenugreek genotypes.

\subsection{Growth and Yield Traits}

According to the results of the two-year study, the effects of genotypes on the plant height of fenugreek were found to be statistically significant at a level of $p<0.01$ (Table 3). The values of plant height for all genotypes were higher in the second year than in the first year of the study, except for the genotype Iraq. According to the two-year averages, the highest plant height value was obtained in the Berkem variety $(78.7 \mathrm{~cm})$ and Kayseri $(78.4 \mathrm{~cm})$ genotypes; the lowest value was found in the Afghanistan $(64.6 \mathrm{~cm})$ genotype. 
Table 3. Average values for the plant heights and first pod heights of fenugreek genotypes.

\begin{tabular}{|c|c|c|c|c|c|c|}
\hline \multirow{2}{*}{ Genotypes } & \multicolumn{3}{|c|}{ Plant Height (cm) } & \multicolumn{3}{|c|}{ First Pod Height (cm) } \\
\hline & 1st Year & 2nd Year & Mean $^{1}$ & 1st Year & 2nd Year & Mean ${ }^{1}$ \\
\hline Adana & $65.8 \mathrm{ef}$ & $73.2 \mathrm{a}-\mathrm{d}$ & $69.5 \mathrm{~d}$ & $30.13 \mathrm{fg}$ & 34.40 def & $32.26 \mathrm{ef}$ \\
\hline Afghanistan & $61.1 \mathrm{f}$ & $68.2 \mathrm{f}$ & $64.6 \mathrm{e}$ & $23.63 \mathrm{~h}$ & $26.90 \mathrm{gh}$ & $25.26 \mathrm{~g}$ \\
\hline Berkem & $78.3 \mathrm{ab}$ & $79.2 \mathrm{a}$ & $78.7 \mathrm{a}$ & $39.88 \mathrm{ab}$ & $43.65 \mathrm{a}$ & $41.76 \mathrm{a}$ \\
\hline Gaziantep & $74.6 \mathrm{abc}$ & $78.2 \mathrm{ab}$ & $76.4 \mathrm{ab}$ & $39.55 \mathrm{abc}$ & $40.23 \mathrm{ab}$ & $39.89 \mathrm{ab}$ \\
\hline Gürarslan & 70.5 cde & $72.9 \mathrm{bcd}$ & $71.7 \mathrm{~cd}$ & 33.63 ef & 35.28 cde & $34.45 \mathrm{~cd}$ \\
\hline Iraq & $73.9 \mathrm{a}-\mathrm{d}$ & $73.3 \mathrm{a}-\mathrm{d}$ & $73.6 \mathrm{bc}$ & $39.55 \mathrm{abc}$ & $36.40 \mathrm{~b}-\mathrm{e}$ & $37.97 \mathrm{bc}$ \\
\hline Kahramanmaraş & $73.7 \mathrm{a}-\mathrm{d}$ & $73.9 \mathrm{a}-\mathrm{d}$ & $73.8 \mathrm{bc}$ & $36.15 \mathrm{~b}-\mathrm{e}$ & $37.03 \mathrm{~b}-\mathrm{e}$ & $36.59 \mathrm{bc}$ \\
\hline Kayseri & $78.3 \mathrm{ab}$ & $78.5 \mathrm{ab}$ & $78.4 \mathrm{a}$ & $27.58 \mathrm{gh}$ & 32.90 ef & $30.24 \mathrm{f}$ \\
\hline Mardin & 71.4 cde & $73.8 \mathrm{a}-\mathrm{d}$ & $72.6 \mathrm{bcd}$ & $37.30 \mathrm{~b}-\mathrm{e}$ & $38.30 \mathrm{bcd}$ & $37.80 \mathrm{bc}$ \\
\hline Şanlıurfa & $73.2 \mathrm{a}-\mathrm{d}$ & $78.9 \mathrm{ab}$ & $75.5 \mathrm{ab}$ & $38.28 \mathrm{bcd}$ & $40.32 \mathrm{ab}$ & $39.20 \mathrm{abc}$ \\
\hline Average & $72.06 \mathrm{~b}$ & $74.87 \mathrm{a}$ & & $34.56 \mathrm{~b}$ & $36.45 \mathrm{a}$ & \\
\hline \multirow{3}{*}{$p$ value } & Year (Y) & \multicolumn{2}{|c|}{$0.0034^{* *}$} & & \multicolumn{2}{|c|}{$0.0449 *$} \\
\hline & Genotype (G) & \multicolumn{2}{|c|}{$0.0001^{* *}$} & & \multicolumn{2}{|c|}{$0.0001 * *$} \\
\hline & $Y \times G$ & \multicolumn{2}{|c|}{$0.0057^{* *}$} & & \multicolumn{2}{|c|}{$0.0007^{* *}$} \\
\hline
\end{tabular}

${ }^{1}$ The difference between the means indicated by the same letter in the same column and group is not significant, $*: p<0.05, * *: p<0.01$.

In the study, when the YxG interaction was examined, the highest value for the plant height was found in the Berkem variety $(79.2 \mathrm{~cm})$ in the second year, the lowest value was found in the Afghanistan $(61.1 \mathrm{~cm}$ ) genotype in the first year (Table 3). From an experiment with 150 genotypes, [33] it was stated that the plant height of fenugreek ranged from 67.07 to $121.23 \mathrm{~cm}$. Average values for the first pod height ranged from 25.26 to $41.76 \mathrm{~cm}$ (Table 3). Plants showed higher average first pod height values in the second year compared to the first year. The $Y \times G$ interaction was found to be statistically significant at a level of $p<0.01$ (Table 3). The genotype Afghanistan showed the lowest first pod height $(23.63 \mathrm{~cm})$ in the first year, and the Berkem variety showed the highest first pod height $(43.65 \mathrm{~cm})$ in the second year. These differences in plant height and first pod height values can be explained by the difference in precipitation regimes over the years.

There was no significant difference in the pod widths of genotypes between the years and $Y \times G$ interaction (Table 4).

Table 4. Average values for pod width and pod length of fenugreek genotypes.

\begin{tabular}{|c|c|c|c|c|c|c|}
\hline \multirow{2}{*}{ Genotypes } & \multicolumn{3}{|c|}{ Pod Width (mm) } & \multicolumn{3}{|c|}{ Pod Length (cm) } \\
\hline & 1st Year & 2nd Year & Mean ${ }^{1}$ & 1st Year & 2nd Year & Mean ${ }^{1}$ \\
\hline Adana & 3.06 & 3.03 & $3.04 \mathrm{ab}$ & 11.72 & 12.98 & $12.35 \mathrm{ab}$ \\
\hline Afghanistan & 2.91 & 2.93 & $2.92 \mathrm{~b}$ & 9.62 & 10.53 & $10.07 \mathrm{e}$ \\
\hline Berkem & 3.00 & 3.30 & $3.15 \mathrm{ab}$ & 11.69 & 12.35 & $12.02 \mathrm{abc}$ \\
\hline Gaziantep & 3.12 & 3.20 & $3.16 \mathrm{ab}$ & 11.58 & 12.13 & $11.85 \mathrm{a}-\mathrm{d}$ \\
\hline Gürarslan & 2.88 & 2.95 & $2.91 \mathrm{~b}$ & 11.49 & 12.70 & $12.09 \mathrm{abc}$ \\
\hline Iraq & 3.06 & 3.05 & $3.06 \mathrm{ab}$ & 10.54 & 11.30 & $10.92 \mathrm{de}$ \\
\hline Kahramanmaraş & 3.21 & 3.28 & $3.24 \mathrm{ab}$ & 11.34 & 12.28 & $11.81 \mathrm{a}-\mathrm{d}$ \\
\hline Kayseri & 3.06 & 3.05 & $3.05 \mathrm{ab}$ & 11.27 & 11.38 & $11.32 \mathrm{~cd}$ \\
\hline Mardin & 3.18 & 3.40 & $3.29 \mathrm{a}$ & 11.17 & 12.05 & $11.61 \mathrm{bcd}$ \\
\hline Şanlıurfa & 3.03 & 3.04 & $3.04 \mathrm{ab}$ & 12.23 & 13.19 & $12.60 \mathrm{a}$ \\
\hline Average & 3.05 & 3.13 & & $11.26 \mathrm{~b}$ & $12.05 \mathrm{a}$ & \\
\hline \multirow{3}{*}{$p$ value } & Year (Y) & \multicolumn{2}{|c|}{$0.1248 \mathrm{~ns}$} & & \multicolumn{2}{|c|}{$0.0005^{* *}$} \\
\hline & Genotype (G) & \multicolumn{2}{|c|}{$0.0154 *$} & & \multicolumn{2}{|c|}{$0.0001 * *$} \\
\hline & $Y \times G$ & \multicolumn{2}{|c|}{$0.8852 \mathrm{~ns}$} & & \multicolumn{2}{|c|}{$0.8012 \mathrm{~ns}$} \\
\hline
\end{tabular}

1 The difference between the means indicated by the same letter in the same column and group is not significant, ns: Not significant, ${ }^{*}: p<0.05,{ }^{* *}: p<0.01$. 
The highest pod width $(3.29 \mathrm{~mm})$ was recorded in the Mardin genotype, followed by Kahramanmaraş (3.24 mm), Gaziantep (3.16 mm), Berkem (3.15 mm), Irak (3.06 mm), Kayseri (3.05 mm), Şanlıurfa and Adana $(3.04 \mathrm{~mm})$. On the other hand, the lowest values were observed in Gürarslan $(2.91 \mathrm{~mm})$, followed by the Afghanistan genotype (2.92 $\mathrm{mm})$. The pod length significantly varied among the genotypes and also differed between the years. The pod length values of all genotypes were higher in the second year $(12.05 \mathrm{~cm})$ than in the first year $(11.26 \mathrm{~cm})$ (Table 4). The lowest value $(10.07 \mathrm{~cm})$ and the highest value $(12.60 \mathrm{~cm})$ were observed in Afghanistan and Şanlıurfa genotypes, respectively. Similar pod lengths ranging from 7.34 to $14.42 \mathrm{~cm}$ among the 150 fenugreek genotypes were observed by [33].

The number of pods per plant significantly varied among the genotypes between the years and their interaction in this study. The values were higher in the first year (15.94 pieces/plant) than in the second year (14.53 pieces/plant) (Table 5). The highest pod number per plant value was obtained from Iraq (18.73 pieces/plant), Gaziantep (18.29 pieces/ plant), Kayseri (17.79 pieces/plant), and Adana (17.75 pieces/plant) genotypes. The lowest values were found Şanlıurfa (12.00 pieces/plant), Afghanistan (12.33 pieces/plant) and Gürarslan (12.35 pieces/plant) genotypes. The study of [34] reported that the number of pods/plant is the most important parameter for selecting high-yielding fenugreek lines due to the positive correlation with seed yield at both genotypic and phenotypic levels. In another study, [33] found a wide range of variations in pods per plant, ranging from 40.7 to 164.4 pods/plant.

Table 5. Average values for the number of pods per plant and seeds per pod of fenugreek genotypes.

\begin{tabular}{|c|c|c|c|c|c|c|}
\hline \multirow{2}{*}{ Genotypes } & \multicolumn{3}{|c|}{ Pod Number per Plant (Piece/Plant) } & \multicolumn{3}{|c|}{ Seed Number per Pod (Piece/Pod) } \\
\hline & 1st Year & 2nd Year & Mean ${ }^{1}$ & 1st Year & 2nd Year & Mean ${ }^{1}$ \\
\hline Adana & $19.50 \mathrm{ab}$ & $16.00 \mathrm{~cd}$ & $17.75 \mathrm{a}$ & 13.53 & 15.80 & $14.66 \mathrm{ab}$ \\
\hline Afghanistan & 11.851 & $12.80 \mathrm{f}-1$ & $12.33 \mathrm{c}$ & 15.05 & 16.05 & $15.55 \mathrm{a}$ \\
\hline Berkem & 14.95 def & $14.65 \mathrm{~d}-\mathrm{g}$ & $14.80 \mathrm{~b}$ & 13.25 & 15.53 & $14.39 \mathrm{ab}$ \\
\hline Gaziantep & $18.40 \mathrm{~b}$ & $18.18 \mathrm{bc}$ & $18.29 \mathrm{a}$ & 12.95 & 14.25 & $13.60 \mathrm{bc}$ \\
\hline Gürarslan & $12.50 \mathrm{~g}-1$ & $12.20 \mathrm{~h} 1$ & $12.35 \mathrm{c}$ & 12.13 & 12.98 & $12.55 \mathrm{c}$ \\
\hline Iraq & $21.30 \mathrm{a}$ & $16.15 \mathrm{~cd}$ & $18.73 \mathrm{a}$ & 15.40 & 15.68 & $15.54 \mathrm{a}$ \\
\hline Kahramanmaraş & $14.25 \mathrm{~d}-\mathrm{h}$ & $13.25 \mathrm{e}-1$ & $13.75 \mathrm{~b}$ & 12.88 & 13.10 & $12.99 \mathrm{bc}$ \\
\hline Kayseri & $19.75 \mathrm{ab}$ & $15.83 \mathrm{~d}$ & $17.79 \mathrm{a}$ & 12.28 & 14.08 & $13.18 \mathrm{bc}$ \\
\hline Mardin & $15.30 \mathrm{de}$ & $13.50 \mathrm{e}-1$ & $14.40 \mathrm{~b}$ & 13.70 & 13.08 & $13.39 \mathrm{bc}$ \\
\hline Şanlıurfa & 11.601 & $12.72 \mathrm{f}-1$ & $12.00 \mathrm{c}$ & 13.35 & 13.02 & $13.26 \mathrm{bc}$ \\
\hline Average & $15.94 \mathrm{a}$ & $14.53 \mathrm{~b}$ & & $13.45 \mathrm{~b}$ & $14.36 \mathrm{a}$ & \\
\hline \multirow{3}{*}{$p$ value } & Year $(\mathrm{Y})$ & $0.0011^{* *}$ & & & $0.0036^{* *}$ & \\
\hline & Genotype (G) & $0.0001^{* *}$ & & & $0.0001^{* *}$ & \\
\hline & $Y \times G$ & $0.0001 * *$ & & & $0.0973 \mathrm{~ns}$ & \\
\hline
\end{tabular}

${ }^{1}$ The difference between the means indicated by the same letter in the same column and group is not significant, ns: Not significant, ${ }^{* *}: p<0.01$.

The number of seeds per pod for all genotypes was higher in the second year than in the first year, except for the Mardin and Şanlıurfa genotypes (Table 5). The highest seed number per pod was found in Afghanistan (15.55 pieces/pod) and Iraq (15.54 pieces/pod) genotypes. There was no difference in seed number per pod of genotypes between $Y x G$ interaction. The genotypes produced more seeds per pod (average) in the second year than in the first year. A lower number of seeds per pod was recorded by [33] compared to our results, where they showed the number of seeds per pod ranging from 7.06 to 12.60. Further, [32] depicted that yield/plant is a necessary trait for selecting fenugreek lines. This difference may be due to the different climatic and soil conditions and the different genotypes used in the research. 


\subsection{Yield and Harvest Index}

This difference between fenugreek genotypes was found to be statistically significant $(p<0.01)$ (Table 6). The biological yields of all genotypes were significantly higher in the second year $\left(8.53 \mathrm{t} / \mathrm{ha}^{-1}\right)$ than in the first year $\left(4.34 \mathrm{t} / \mathrm{ha}^{-1}\right)$. According to the two-year averages, the biological yields were between 5.12 and $7.62 \mathrm{t} / \mathrm{ha}^{-1}$. In the study, the YxG interaction was found to be statistically insignificant.

The seed yield was significant among the genotypes, and the variation between the years was also remarkable. The average values for seed yields varied from 0.76 to $1.44 \mathrm{t} / \mathrm{ha}^{-1}$ in the first year and 1.06 to $1.37 \mathrm{t} / \mathrm{ha}^{-1}$ in the second year (Table 6 ). The lowest seed yield $\left(0.76 \mathrm{t} / \mathrm{ha}^{-1}\right)$ was observed in Iraq, and the highest $\left(1.44 \mathrm{t} / \mathrm{ha}^{-1}\right)$ was observed in the Mardin genotype. In addition, since the response of genotypes to environmental conditions is different, year $\times$ genotype interaction has been important in seed yield, as well as in many other characteristics.

Table 6. Average values for biological yields and seed yields of fenugreek genotypes.

\begin{tabular}{|c|c|c|c|c|c|c|}
\hline \multirow{2}{*}{ Genotypes } & \multicolumn{3}{|c|}{ Biological Yield $\left(\mathrm{t} / \mathrm{ha}^{-1}\right)$} & \multicolumn{3}{|c|}{ Seed Yield $\left(\mathrm{t} / \mathrm{ha}^{-1}\right)$} \\
\hline & 1st Year & 2nd Year & Mean $^{1}$ & 1st Year & 2nd Year & Mean $^{1}$ \\
\hline Adana & 3.82 & 9.11 & $6.47 \mathrm{abc}$ & $1.24 \mathrm{a}-\mathrm{d}$ & $1.28 \mathrm{a}-\mathrm{d}$ & $1.26 \mathrm{a}$ \\
\hline Afghanistan & 3.18 & 7.07 & $5.12 \mathrm{c}$ & 0.98 def & $1.11 \mathrm{~b}-\mathrm{e}$ & $1.04 \mathrm{bc}$ \\
\hline Berkem & 5.36 & 9.88 & $7.62 \mathrm{a}$ & $1.39 \mathrm{ab}$ & $1.37 \mathrm{abc}$ & $1.38 \mathrm{a}$ \\
\hline Gaziantep & 4.24 & 8.76 & $6.50 \mathrm{abc}$ & $1.01 \mathrm{def}$ & $1.09 \mathrm{~b}-\mathrm{e}$ & $1.05 \mathrm{bc}$ \\
\hline Gürarslan & 4.42 & 7.50 & $5.96 \mathrm{abc}$ & 0.91 ef & $1.10 \mathrm{~b}-\mathrm{e}$ & $1.01 \mathrm{c}$ \\
\hline Iraq & 3.10 & 7.52 & $5.31 \mathrm{bc}$ & $0.76 \mathrm{f}$ & $1.06 \mathrm{c}-\mathrm{f}$ & $0.91 \mathrm{c}$ \\
\hline Kahramanmaraş & 5.40 & 9.07 & $7.23 \mathrm{ab}$ & $1.24 \mathrm{a}-\mathrm{d}$ & $1.20 \mathrm{a}-\mathrm{e}$ & $1.22 \mathrm{ab}$ \\
\hline Kayseri & 4.58 & 9.08 & $6.83 \mathrm{abc}$ & $1.37 \mathrm{abc}$ & $1.18 \mathrm{a}-\mathrm{e}$ & $1.27 \mathrm{a}$ \\
\hline Mardin & 4.51 & 8.09 & $6.30 \mathrm{abc}$ & $1.44 \mathrm{a}$ & $1.24 \mathrm{a}-\mathrm{d}$ & $1.34 \mathrm{a}$ \\
\hline Şanlıurfa & 4.82 & 9.28 & $7.05 \mathrm{abc}$ & $1.28 \mathrm{a}-\mathrm{d}$ & $1.20 \mathrm{a}-\mathrm{e}$ & $1.24 \mathrm{ab}$ \\
\hline Average & $4.34 \mathrm{~b}$ & $8.53 \mathrm{a}$ & & 1.16 & 1.18 & \\
\hline \multirow{3}{*}{$p$ value } & Year $(Y)$ & $0.0001 * *$ & & & $0.589 \mathrm{~ns}$ & \\
\hline & Genotype (G) & 0.0018 ** & & & $0.0001 * *$ & \\
\hline & $Y \times G$ & $0.8335 \mathrm{~ns}$ & & & $0.0014^{* *}$ & \\
\hline
\end{tabular}

${ }_{1}^{1}$ The difference between the means indicated by the same letter in the same column and group is not significant, ns: Not significant, ${ }^{* *}: p<0.01$.

Significantly higher biological yields in the second year (from all genotypes) were found in the harvest index (HI), where significant reductions were observed in the $\mathrm{HI}$ in the second year compared to the first year (Table 7).

Table 7. Average values for the harvest index (HI) and thousand-seed weight of fenugreek genotypes.

\begin{tabular}{ccccccc}
\hline \multirow{2}{*}{ Genotypes } & \multicolumn{3}{c}{ Harvest Index (\%) } & \multicolumn{3}{c}{ Thousand-Seed Weight (g) } \\
\cline { 2 - 7 } & 1st Year & 2nd Year & Mean ${ }^{\mathbf{1}}$ & 1st Year & 2nd Year & Mean ${ }^{\mathbf{1}}$ \\
\hline Adana & $32.54 \mathrm{a}$ & $14.13 \mathrm{ef}$ & $23.34 \mathrm{ab}$ & 15.62 & 15.54 & $15.58 \mathrm{c}$ \\
Afghanistan & $32.80 \mathrm{a}$ & $15.91 \mathrm{c}-\mathrm{f}$ & $24.35 \mathrm{a}$ & 14.99 & 15.09 & $15.04 \mathrm{c}$ \\
Berkem & $25.96 \mathrm{abc}$ & $14.41 \mathrm{ef}$ & $20.18 \mathrm{bc}$ & 16.53 & 16.95 & $16.74 \mathrm{abc}$ \\
Gaziantep & $24.25 \mathrm{a}-\mathrm{e}$ & $12.64 \mathrm{f}$ & $18.45 \mathrm{c}$ & 16.97 & 17.09 & $17.03 \mathrm{ab}$ \\
Gürarslan & $20.93 \mathrm{~b}-\mathrm{f}$ & $14.89 \mathrm{def}$ & $17.91 \mathrm{c}$ & 17.30 & 17.61 & $17.45 \mathrm{a}$ \\
Iraq & $24.87 \mathrm{a}-\mathrm{d}$ & $14.25 \mathrm{ef}$ & $19.56 \mathrm{bc}$ & 13.60 & 14.13 & $13.87 \mathrm{~d}$ \\
Kahramanmaraş & $22.89 \mathrm{a}-\mathrm{f}$ & $13.59 \mathrm{f}$ & $18.24 \mathrm{c}$ & 16.88 & 17.08 & $16.98 \mathrm{ab}$ \\
Kayseri & $29.87 \mathrm{ab}$ & $13.43 \mathrm{f}$ & $21.65 \mathrm{abc}$ & 16.81 & 17.09 & $16.95 \mathrm{ab}$ \\
Mardin & $32.89 \mathrm{a}$ & $15.51 \mathrm{def}$ & $24.20 \mathrm{a}$ & 16.07 & 16.12 & $16.09 \mathrm{bc}$ \\
Şanliurfa & $26.57 \mathrm{ab}$ & $13.06 \mathrm{f}$ & $19.82 \mathrm{bc}$ & 17.43 & 16.23 & $16.83 \mathrm{ab}$ \\
\hline Average & $27.36 \mathrm{a}$ & $14.18 \mathrm{~b}$ & & 16.22 & 16.29 \\
\hline value & Year $(\mathrm{Y})$ & $0.0001 * *$ & & & $0.5653 \mathrm{~ns}$
\end{tabular}

1 The difference between the means indicated by the same letter in the same column and group is not significant, ns: Not significant, ${ }^{* *}: p<0.01$. 
According to the two-year averages, the highest $\mathrm{HI}$ values were obtained in Afghanistan $(24.35 \%)$ and Mardin $(24.20 \%)$ genotypes, and the lowest values were found in Gürarslan $(17.91 \%)$, Kahramanmaraş (18.24\%), and Gaziantep (18.45\%) genotypes. The $Y \times$ G interaction was found to be statistically significant at a level of $p<0.01$ (Table 7). The lowest $\mathrm{HI}(12.64 \%)$ was observed in the Gaziantep genotype in the second year, and the highest $(32.89 \%)$ was observed in the Mardin genotype in the first year. The averages of HI values were higher in the first year compared to the second year. McCormick et al. [32] declared the important traits for the yield of biological yield and HI.

According to the results of the two-year study, the effects of genotypes on thousandseed weight were found to be statistically significant at a level of $p<0.01$ (Table 7). In the study, the YxG interaction for thousand-seed weight was found to be statistically insignificant. Thousand-seed weight values of all genotypes were higher in the second year than in the first year, except for the Adana and Şanlıurfa genotypes (Table 7). The average values for thousand-seed weights diverged from 13.60 to $17.43 \mathrm{~g}$ in the first year and 14.13 to $17.61 \mathrm{~g}$ in the second year. Statistically, it was seen that there was no difference in the thousand-seed weight of genotypes between years. When two years averages were evaluated, the genotype Güraraslan showed the highest thousand-seed weight (17.45 g), while the Irak genotype showed the lowest weight $(13.87 \mathrm{~g})$. Thousand-seed weight is a significant trait for high-yielding fenugreek genotypes [32,34].

\subsection{Quality Traits}

According to variance analysis, years and $Y x G$ interaction between genotypes in terms of fatty oil ratio and yields were found to be statistically nonsignificant. The average values for fatty oil ratios varied from 5.18 to $9.16 \%$ (Table 8 ).

Table 8. Average values for fatty oil content and fatty oil yield of fenugreek genotypes.

\begin{tabular}{ccccccc}
\hline \multirow{2}{*}{ Genotypes } & \multicolumn{3}{c}{ Fatty Oil Ratio (\%) } & \multicolumn{3}{c}{ Fatty Oil Yield (kg ha $\left.{ }^{-1}\right)$} \\
\cline { 2 - 7 } & 1st Year & 2nd Year & Mean ${ }^{\mathbf{1}}$ & 1st Year & 2nd Year & Mean $^{\mathbf{1}}$ \\
\hline Adana & 5.87 & 5.99 & $5.93 \mathrm{c}$ & 72.7 & 76.9 & $74.8 \mathrm{c}$ \\
Afghanistan & 8.92 & 9.40 & $9.16 \mathrm{a}$ & 86.9 & 104.0 & $95.4 \mathrm{~b}$ \\
Berkem & 7.98 & 8.24 & $8.11 \mathrm{~b}$ & 110.6 & 112.7 & $111.6 \mathrm{a}$ \\
Gaziantep & 5.31 & 5.37 & $5.34 \mathrm{~cd}$ & 53.6 & 58.6 & $56.0 \mathrm{de}$ \\
Gürarslan & 6.05 & 5.98 & $6.02 \mathrm{c}$ & 55.2 & 66.1 & $60.7 \mathrm{cde}$ \\
Iraq & 5.30 & 5.48 & $5.39 \mathrm{~cd}$ & 40.5 & 58.2 & $49.3 \mathrm{e}$ \\
Kahramanmaraş & 5.93 & 6.02 & $5.97 \mathrm{c}$ & 73.3 & 72.1 & $72.7 \mathrm{c}$ \\
Kayseri & 5.37 & 5.32 & $5.34 \mathrm{~cd}$ & 73.4 & 62.8 & $68.1 \mathrm{~cd}$ \\
Mardin & 5.47 & 5.59 & $5.53 \mathrm{~cd}$ & 78.8 & 69.9 & $74.3 \mathrm{c}$ \\
Şanliurfa & 5.04 & 5.33 & $5.18 \mathrm{~d}$ & 64.4 & 63.9 & $64.1 \mathrm{cde}$ \\
\hline Average & 6.12 & 6.27 & & 70.9 & 74.5 & \\
\hline value & Year $(\mathrm{Y})$ & $0.1747 \mathrm{~ns}$ & & & $0.1850 \mathrm{~ns}$ & \\
& Genotype (G) & $0.0001 * *$ & & & $0.0001 * *$ & \\
& $\mathrm{Y} \times \mathrm{G}$ & $0.9802 \mathrm{~ns}$ & & & $0.0656 \mathrm{~ns}$ & \\
\hline
\end{tabular}

${ }_{1}^{1}$ The difference between the means indicated by the same letter in the same column and group is not significant, ns: Not significant, ${ }^{*}: p<0.05$.

The Şanliurfa genotype showed the lowest ratio (5.18\%), and the Afghanistan variety showed the highest fatty oil ratio $(9.16 \%)$. Statistically similar fatty oil yields were observed between the years. Saxena et al. [23] found the variation in fatty oil content among the genotypes ranged from 2.62 to $5.33 \%$. Beyzi et al. [35] reported the fatty oil content of fenugreek as between $4.75 \%$ and $5.54 \%$. Ciftci et al. [36] stated that the oil content of fenugreek ranged from 5.8 to $15.2 \%$. Compared to these findings, the fatty oil ratios $(5.18-9.16 \%)$ were lower than the results of [23,36], but higher than the findings of [35]. The Iraq genotype exhibited the lowest two-year average fatty oil yield $\left(49.3 \mathrm{~kg} \mathrm{ha}^{-1}\right)$, and the Berkem variety exhibited the highest fatty oil yield (111.6 $\left.\mathrm{kg} \mathrm{ha}^{-1}\right)$. Muhammed et al. [37] 
stated that the oil yield varies according to the varieties between 65.9 and $83.9 \mathrm{~kg} \mathrm{ha}^{-1}$. Our oil yield findings [37] were noted above the reported values. This is due to the difference in genotype and cultural processes.

The Trigonelline ratio in seeds of fenugreek genotypes fluctuated between 0.71 and $1.32 \%$, and the lowest ratio was recorded in the Berkem variety and the highest in the Gaziantep genotype (Table 9). Özyazıc1 [38] reported the trigonelline content of fenugreek as $1.26 \%$. Mutlu [19] reported in a study conducted on fenugreek of different origins that the trigonelline content varied between 0.66 and $1.40 \%$. The trigonelline ratios obtained from this study are within the values reported by $[19,36]$.

Table 9. Trigonelline ratio of fenugreek genotypes.

\begin{tabular}{cc}
\hline Genotypes & Trigonelline Ratio (\%) \\
\hline Adana & 0.91 \\
Afghanistan & 0.86 \\
Berkem & 0.71 \\
Gaziantep & 1.32 \\
Gürarslan & 0.96 \\
Iraq & 0.78 \\
Kahramanmaraş & 0.94 \\
Kayseri & 1.04 \\
Mardin & 1.12 \\
Şanliurfa & 1.09 \\
\hline Ortalama & 0.97 \\
\hline
\end{tabular}

\section{Conclusions}

Fenugreek genotypes were obtained from different local and international locations; Yield and quality characteristics in semiarid climatic conditions in terms of the year, soil, and climate showed different responses. As a result of the research, a few genotypes were determined to be close to Turkey's registered Berkem variety in terms of yield and quality. Especially from the Mardin, Kayseri, and Adana genotypes, yields close to the Berkem variety were obtained. While the Gaziantep genotype stands out in trigonelline content, the highest fatty oil content was found in the Afghanistan genotype. When all these results are evaluated together, it is concluded that Mardin, Kayseri, Adana, Gaziantep, and Afghanistan can be used in breeding studies.

Author Contributions: Problem identification and construction of in silico pipeline, Y.G., G.Ö.; data retrieval, Y.G., G.Ö.; data analysis and data interpretation, Y.G., G.Ö.; manuscript writing, Y.G., G.Ö.; writing - review and editing, G.Ö.; funding acquisition, G.Ö. All authors have read and agreed to the published version of the manuscript.

Funding: This research received no external funding.

Institutional Review Board Statement: Not applicable.

Informed Consent Statement: Not applicable.

Data Availability Statement: Data is contained within the article.

Acknowledgments: The study's first-year data was part of the M.Sc Thesis of the first author entitled "Determination of Yield and Some Quality Components of Fenugreek (Trigonella foenum-graecum L.) Genotypes" accepted by the Institute of Natural and Applied Sciences of Siirt University. The authors thank Ayman EL SABAGH (Siirt University, Faculty of Agriculture, Department of Field Crops, Siirt 56100, Turkey) for critically reviewing the manuscript.

Conflicts of Interest: The authors declare no conflict of interest. 


\section{References}

1. Baydar, H. Science and Technology of Medicinal and Aromatic Plants; Nobel Book Publications: Ankara, Turkey, 2020; 420p. (In Turkish)

2. Sewell, R.D.E.; Rafieian-Kopaei, M. The history and ups and downs of herbal medicine usage. J. HerbMed Pharmacol. 2014, 3, 1-3.

3. Baradaran, A.; Nasri, H.; Nematbakhsh, M.; Rafieian-Kopaei, M. Antioxidant activity and preventive effect of aqueous leaf extract of Aloe Vera on gentamicin-induced nephrotoxicity in male Wistar rats. Clin. Ter. 2014, 165, 7-11.

4. Nasri, H.; Tavakoli, M.; Ahmadi, A.; Baradaran, A.; Nematbakhsh, M.; Rafieian-Kopaei, M. Ameliorative effect of melatonin against contrast media induced renal tubular cell injury. Pak. J. Med. Sci. 2014, 30, 261-265.

5. Yadav, U.C.S.; Baquer, N.Z. Pharmacological effects of Trigonella foenum-graecum L. in health and disease. Pharm. Biol. 2014, 52, 243-254. [CrossRef] [PubMed]

6. Nair, R.; Pandey, S.K. Performance of potential fenugreek genotypes for seed yield and its attributing traits in vertisols of Central India. Int. J. Chem. Stud. 2020, 8, 3071-3072. [CrossRef]

7. Açıkbaş, S.; Özyazıcı, M.A. The evaluation in terms of forage quality of toxic substances found in some forage crops. In Proceedings of the II International Hazar Scientific Researches Conference, Baku, Azerbaijan, 10-12 April 2021; pp. 853-864.

8. Altuntaş, E.; Özgöz, E.; Taşer, Ö.F. Some physical properties of fenugreek (Trigonella foenum-graceum L.) seeds. J. Food Eng. 2005, 71, 37-43. [CrossRef]

9. Bahmani, M.; Hedayatollah, S.; Mirhosseini, M.; Mesripour, A.; Rafieian-Kopaei, M. A review on ethnobotanical and therapeutic uses of fenugreek (Trigonella foenum-graceum L.). J. Evid.-Based Complement. Altern. Med. 2016, 21, 53-62. [CrossRef]

10. Minorsky, P.V. Trigonelline: A diverse regulator in plants. Plant Physiol. 2002, 128, 7-8. [CrossRef]

11. Yao, D.; Zhang, B.; Zhu, J.; Zhang, Q.; Hu, Y.; Wang, S.; Wang, Y.; Cao, H.; Xiao, J. Advances on application of fenugreek seeds as functional foods: Pharmacology, clinical application, products, patents and market. Crit. Rev. Food Sci. Nutr. 2020, 60, $2342-2352$. [CrossRef]

12. Basch, E.; Ulbricht, C.; Kuo, G.; Szapary, P.; Smith, M. Therapeutic applications of fenugreek. Altern. Med. Rev. $2003,8,20-27$.

13. Dharajiya, D.; Jasani, H.; Khatrani, T.; Kapuria, M.; Pachchıgarr, K.; Patel, P. Evaluation of antibacterial and antifungal activity of fenugreek (Trigonella foenum-graecum L.) extracts. Int. J. Pharm. Pharm. Sci. 2016, 8, 212-217.

14. TUIK. Crop Production Statistics. Turkish Statistical Institute. 2021. Available online: https://data.tuik.gov.tr/Kategori/ GetKategori? $\mathrm{p}=$ tarim-111\&dil=1 (accessed on 11 January 2021).

15. Perry, L.M. Medicinal Plants of East and Southeast Asia: Attributed Properties and Uses; The MIT Press: Cambridge, UK, 1980.

16. Ionescu, A.M.; Roman, G.V. Research on biology, productivity and yield quality of Trigonella foenum-graecum L. species (fenugreek) in the central part of the South Romanian plain. Agronomy 2013, 56, 395-397.

17. Kevseroğlu, K.; Özyazıcı, G. Effects of nitrogenous fertilizer doses on some agricultural characteristics of fenugreek (Trigonella foenum-graecum L.) plant. In Proceedings of the Turkey II Field Crops Congress, Samsun, Turkey, 22-25 September 1997; pp. 367-371. (In Turkish)

18. Aydın, A. Determination of Some Significant Morphologic, Fenological and Quality Criterion in Different Origins of Fenugreek (Trigonella foenum-graecum L.) Populations. Master's Thesis, The Graduate School of Natural and Applied Science of Siirt University, Samsun, Turkey, 2010; p. 56. (In Turkish)

19. Mutlu, S. Determination of Some Phenological, Morphological, Yield and Quality Characteristics of Fenugreeks (Trigonella foenum-graecum L.) from Different Origins. Master's Thesis, The Graduate School of Natural and Applied Science of Ondokuz Mayıs University, Samsun, Turkey, 2011; p. 88. (In Turkish)

20. Akbay, F.; Erol, A. Evaluation of different fenugreek genotypes in terms of agricultural and morphological characteristics. In Proceedings of the International Agricultural Congress of Muş Plain, Muş, Turkey, 24-27 September 2019; pp. 120-131. (In Tukish)

21. Başbağ, M.; Tonçer, Ö. A study on determination of yield and yield criteria of some fenugreek (Trigonella foenum-graecum L.) lines in Diyarbakır conditions. In Proceedings of the Turkey VI Field Crops Congress, Antalya, Turkey, 5-9 September 2005; pp. 1117-1122. (In Turkish)

22. Çamlıca, M.; Yaldız, G. Characterization of morphological and yield variation of fenugreek (Trigonella foenum-graecum L.) genotypes. Legume Res. 2019, 42, 500-504. [CrossRef]

23. Saxena, S.N.; Kakani, R.K.; Sharma, L.K.; Agarwal, D.; John, S.; Sharma, Y. Effect of water stress on morpho-physiological parameters of fenugreek (Trigonella foenum-graecum L.) genotypes. Legume Res. 2019, 42, 60-65. [CrossRef]

24. Chaudhary, S.; Chaudhary, P.S.; Chikara, S.K.; Sharma, M.C.; Iriti, M. Review on fenugreek (Trigonella foenum-graecum L.) and its important secondary metabolite diosgenin. Not. Bot. Horti Agrobot. Cluj-Napoca 2018, 46, 22. [CrossRef]

25. Kumar, S.; Meena, R.S.; Lal, R.; Yadav, G.S.; Mitran, T.; Meena, B.L.; Mohan Lal Dotaniya, M.L.; El-Sabagh, A. Role of Legumes in Soil Carbon Sequestration. In Legumes for Soil Health and Sustainable Management, 1st ed.; Meena, R.S., Das, A., Yadav, G.S., Lal, R., Eds.; Springer Nature: Singapore, 2018; pp. 109-138.

26. Hassanzadeh, E.; Chaichi, M.R.; Mazaheri, D.; Rezazadeh, S.; Badi, H.A.N. Physical and chemical variabilities among domestic Iranian fenugreek (Trigonella foenum-graceum) seeds. Asian J. Plant Sci. 2011, 10, 323-330. [CrossRef]

27. Anonymous. Climate Data of Siirt Province; General Directorate of Meteorology: Ankara, Turkey, 2020.

28. Van Wambeke, A.R. The Newhall Simulation Model for Estimating Soil Moisture and Temperature Regimes; Department of Crop and Soil Sciences, Cornell University: Ithaca, NY, USA, 2000. 
29. Anonymous. Fenugreek (Trigonella foenum-graecum L.) Registration Report, "Berkem"; T.C. Ministry of Food, Agriculture and Livestock Seed Registration and Certification Center: Ankara, Turkey, 2015. Available online: https://www.tarimorman.gov.tr/ BUGEM/TTSM/Belgeler/Duyuru\%20Belgeleri/2015\%20tescil/T\%C4\%B1bbi\%20Aromatik/tescil\%20raporlar\%C4\%B1/2015_ \%C3\%A7emen_tescil_raporu_fyd.pdf (accessed on 23 October 2020). (In Turkish)

30. Tunçtürk, R. The effects of various fertilizer sources, sowing dates and bacteria inoculation on the yield and yield companents of fenugreek (Trigonella foenum graecum L.) in Van ecological conditions. Ph.D. Thesis, The Graduate School of Natural and Applied Science of Yüzüncü Yıl University, Van, Turkey, 2010; p. 177. (In Turkish)

31. Açıgöz, N.; Açıgöz, N. Some mistakes made in the statistical evaluation of agricultural research: I. Single Factor Trials. Anadolu 2001, 11, 135-147. (In Turkish)

32. McCormick, K.M.; Norton, R.M.; Eagles, H.A. Phenotypic variation within a fenugreek (Trigonella foenum-graecum L.) germplasm collection. II. Cultivar selection based on traits associated with seed yield. Genet. Resour. Crop. Evol. 2009, 56, 651-661. [CrossRef]

33. Mamatha, N.C.; Tehlan, S.K.; Srikanth, M.; Ravikumar, T.; Batra, V.K.; Karthik Reddy, P.; Nalla, M.K. Mean performance of 150 fenugreek (Trigonella foenum-graecum L.) genotypes for yield and yield contributing traits. Int. J. Pure App. Biosci. 2017, 5 , 1097-1102.

34. Sharma, K.C.; Sastry, E.V.D. Path analysis for seed yield and its component characters in fenugreek (Trigonella foenum-graecum L.). J. Spices Aromat. Crop. 2008, 17, 69-74.

35. Beyzi, E.; Köngül Şafak, E.; Gürbüz, P.; Koşar, M.; Gürbüz, B. Fatty acid composition, diosgenin and trigonelline contents of fenugreek (Trigonella foenum-graecum): Effects of phosphorus fertilizer. Plant Biosyst.—Int. J. Deal. All Asp. Plant Biol. 2021, 155, 663-667.

36. Ciftci, O.N.; Przybylski, R.; Rudzinska, M.; Acharya, S. Characterization of fenugreek (Trigonella foenum-graecum) seed lipids. J. Am. Oil Chem. Soc. 2011, 88, 1603-1610. [CrossRef]

37. Muhamme, K.E.; Ahmed, R.M.; Muhamma, A.G. Response of seed yield and its component of Fenugreek (Trigonella foenumgraecum L.) variety to nitrogen fertilizer under rainfed condition. J. Kerbala Agric. Sci. 2018, 5, 38-44.

38. Özyazıc1, G. Responses of sulfur and phosphorus doses on the yield and quality of fenugreek (Trigonella foenum-graecum L.). Appl. Ecol. Environ. Res. 2020, 18, 7041-7055. [CrossRef] 